No 4078

Studia nad Autorytaryzmem i Totalitaryzmem 43, nr 4 Wrocław 2021

https://doi.org/10.19195/2300-7249.43.4.32

\author{
MACIEJ SKORY \\ ORCID: 0000-0002-1116-3169 \\ Uniwersytet Wrocławski \\ maciej.skory@uwr.edu.pl
}

\title{
Wpływ ideologii totalitarnych na konstrukcje prawne stosowane w zakresie ograniczania autonomii woli jednostki na przykładzie modeli wiązania wzorców umownych
}

\author{
Słowa kluczowe: autonomia woli jednostki, ideologie totalitarne, mechanizm wiązania wzor- \\ ców umownych.

\begin{abstract}
INFLUENCE OF TOTALITARIAN IDEOLOGIES ON LEGAL CONSTRUCTIONS
APPLIED IN THE FIELD OF LIMITING THE AUTONOMY OF AN INDIVIDUAL'S

WILL BASED ON THE EXAMPLE OF MODELS OF BINDING CONTRACTUAL STANDARD FORMS
\end{abstract}

\begin{abstract}
The paper aims to examine the influence of totalitarian ideologies on the issue of the mechanism of binding contractual standard forms. Although totalitarian ideologies mainly influence the situation of an individual through the norms of criminal law and administrative law (public law in its broadest sense), private law - especially in its theoretical aspect involving accepted legal constructs - is also influenced by the political doctrines dominant at a given time. As it seems, this also applies to such a technical and far-from-political model as that of contractual binding. It turns out that also in this area totalitarian concepts found room for restricting the scope of individual freedom. This is indicated by a certain correlation between the development of views on the nature of contractual forms and the mechanism of their binding and the intensification or weakening of totalitarian tendencies. Such a conclusion can be derived from the historical analysis of the views represented by the main representatives of French and German doctrine from the mid-19th to the mid-20th century.
\end{abstract}

Keywords: autonomy of individual will, totalitarian ideologies, mechanism of biding contractual standard forms. 
Ideologie totalitarne to pojęcie nieostre, obejmujące koncepcje polityczne, które bez wątpienia należy włączyć do tej kategorii, oraz takie, które tylko częściowo odpowiadają słownikowej definicji. Problem zresztą dotyczy nie tylko ideologii (z natury trudnej do precyzyjnego ujęcia), ale także samego zjawiska totalitaryzmu oznaczającego system rządów oparty na obowiązującej wszystkich ideologii, w którym państwo w pełni kontroluje społeczeństwo i stara się nadzorować wszystkie aspekty życia. Od roku 1923, kiedy to Giovanni Amendola ukuł termin totalitario, jego znaczenie - początkowo stosowane w odniesieniu do faszyzmu włoskiego, później także niemieckiego nazizmu, aż wreszcie do ustroju ZSRR - ulegało pewnym modyfikacjom. Przykładowo w ostatnim z wymienionych państw wielu teoretyków podkreśla, że określeniem tym w ścisłym znaczeniu można operować w zasadzie w odniesieniu do okresu stalinizmu. Dla potrzeb niniejszego opracowania wskazane rozbieżności nie mają jednak znaczenia, gdyż sednem dalszych rozważań jest wpływ ideologii totalitarnych na pewien wąski wycinek wolności jednostki, niezależnie od miejsca (państwa) i czasu, w jakim wpływ ten się uwidacznia. Chodzi zatem o oddziaływanie na poziomie konstrukcyjnoprawnym, a nie faktyczne w konkretnym państwie totalitarnym czy autorytarnym. Wszak okres PRL — zwłaszcza schyłkowy — nie może być bezkrytycznie zrównany z radzieckim stalinizmem czy hitleryzmem, choć bez wątpienia wpływy ideologiczne tych ostatnich zaznaczały się zarówno w podstawach ustrojowych komunistycznej Polski, jak i stosowanych konstrukcjach prawnych, dogmatach, głoszonych wartościach.

Powszechnie przyjmuje się, że totalitaryzm obejmuje szeroko pojętą sferę publiczną. Niewątpliwie w jej ramach koncentruje się jego niszcząca siła. Prawo publiczne bowiem posługuje się nakazami i zakazami, z pomocą których najłatwiej sterować zachowaniami społecznymi, czy to poprzez normy prawa administracyjnego, czy karnego. Obszar prawa publicznego reguluje przecież stosunki pomiędzy jednostką a społeczeństwem (szeroko pojętym państwem). Normy publicznoprawne w swym konstrukcie zawierają podporządkowanie. Tymczasem prawo prywatne (cywilne) reguluje stosunki pomiędzy (z założenia) równymi sobie podmiotami — obywatelami (civitas-obywatel). W takiej relacji - przynajmniej formalnie - nie ma miejsca na poddanie, podporządkowanie, zależność, co wprost prowadzi do pojęcia wolności stanowiącej fundament stosunków cywilnoprawnych.

Przybliżeniem pojęcia autonomii woli $\mathrm{w}$ prawie cywilnym zajął się Jacek Kaczor $\mathrm{w}$ intersującym opracowaniu zatytułowanym Zasada autonomii woli $w$ świetle filozofii liberalnej ${ }^{1}$. Przypomniał on, że tradycyjnie za fundament współczesnej cywilistyki, nadający kształt zarówno regulacjom prawnym, jak i narzędziom służącym kształtowaniu sytuacji prawnej podmiotów, uważa się zasadę autonomii woli. Dalej autor ten twierdzi, że podstawę wyodrębnienia prawa

1 „Ruch Prawniczy, Ekonomiczny i Socjologiczny” 2001, nr 1-2, s. 2. 
cywilnego, a nawet szerzej — prawa prywatnego w ogóle — stanowi szczególna metoda regulacji stosunków cywilnoprawnych opierająca się na uznaniu autonomicznej pozycji podmiotów tych stosunków, a pomiędzy zasadą autonomii woli a cywilistyczną metodą regulacji stosunków prawnych istnieje oczywista więź treściowa. Sam termin autonomia woli jest w cywilistyce pojęciem legitymującym się długą tradycją, a przy tym w miarę jednoznacznie rozumianym. Autor ten podkreśla jednak, że mimo tak istotnego znaczenia omawianego terminu w prawie cywilnym daje się zauważyć pewne nieuporządkowanie terminologiczne - w różnego rodzaju opracowaniach mówi się o autonomii woli, autonomii podmiotów, autonomii prywatnej, swobodzie czynności prawnych, wolności (swobodzie) kontraktowania oraz swobodzie umów, często używając tych terminów jako równoznacznych. Natomiast autonomia woli (autonomia prywatna, autonomia podmiotów) i swoboda czynności prawnych są terminami o zbliżonym znaczeniu, albowiem odnoszą się do wszystkich czynności prawnych. Natomiast swoboda umów czy też wolność kontraktowa mają za przedmiot tylko jeden z ich rodzajów, a mianowicie - umowy. Z uwagi na zakres niniejszego opracowania pojęcie autonomia woli jednostki będzie występowało zasadniczo w kontekście zasady swobody umów, niemniej jednak polityczno-ustrojowy kontekst pracy wskazuje na potrzebę odniesienia przeprowadzonych rozważań do autonomii woli także w szerszym znaczeniu.

Systemy totalitarne dla zniewolenia jednostki i pozbawienia jej przyrodzonej swobody działania z powodzeniem mogą posługiwać się wyłącznie instrumentarium publicznoprawnym (karnym, administracyjnym), wspomniany obszar wolności stanowiący immanentną cechę prawa cywilnego dla wyznawców ideologii totalitarnej jest pewnym zagrożeniem. Dlatego właśnie w obszarze prawa prywatnego należy nie tyle zastanawiać się nad istotą wolności, ale nad granicami wolności oraz sposobami jej wyznaczania. Jasne jest, że nieograniczona wolność prowadzi do anarchii, a z czasem do wolności jako takiej. Tradycyjnie w prawie cywilnym wolność manifestowana jest poprzez zasadę swobody umów ${ }^{2}$, której granice wyznacza art. $353^{1}$ kodeksu cywilnego ${ }^{3}$. Przepis ten stanowi jednocześnie źródło dla doktrynalnego pojęcia tak zwanej autonomii woli jednostki, która jest centralną kategorią prawa prywatnego. W ujęciu historycznym zakres i rozumienie tego pojęcia ulegały zmianom, a działo się to pod wpływem obowiązującej ideologii. W okresie dominacji nurtów liberalnych (w początkach lat dziewięćdziesiątych XX wieku), autonomia woli jednostki uznawana była za niemal nieograniczoną, totalną (sic!) wręcz. Obecnie liberalizm podlega coraz większej

2 Warto w tym miejscu wspomnieć, że to naturalne odwołanie do wolności w prawie umów już nie jest takie oczywiste w prawie rzeczowym (choć poprzez numerus clausus praw rzeczowych) lub nawet spadkowym czy rodzinnym.

3 Strony zawierające umowę mogą ułożyć stosunek prawny według swego uznania, byleby jego treść lub cel nie sprzeciwiały się właściwości (naturze) stosunku, ustawie ani zasadom współżycia społecznego. 
krytyce, rewidowane są jego założenia, podważane podstawy, kwestionowane znaczenie ${ }^{4}$, stąd też i zakres autonomii woli jednostki ulega zawężeniu; na wielu zresztą płaszczyznach. Zawężenie to spowodowane jest nie tylko pobudkami ideologicznymi, ale obserwacją rzeczywistości i coraz większym doświadczeniem w stosowaniu prawa. Erich Fromm ${ }^{5}$ zauważył swoiste ujemne sprzężenie zwrotne pomiędzy wolnością a bezpieczeństwem: im więcej bezpieczeństwa, tym mniej wolności, im więcej wolności, tym mniej bezpieczeństwa. Reguła ta daje się zauważyć także w regulacjach stosunków cywilnoprawnych. We wspomnianym okresie dominacji nurtów liberalnych jednostka korzystała z szerokiej wolności w obrocie cywilnoprawnym, w szczególności gospodarczym, z czym wiązał się szereg zagrożeń polegających na nadużyciu siły kontraktowej. Doskonałą egzemplifikacją tych zjawisk były ograniczenia we wspomnianej już zasadzie swobody umów wprowadzone poprzez przepisy o klauzulach abuzywnych. W Europie ich źródłem jest Dyrektywa Rady 93/13/EWG z 5 kwietnia 1993 roku, do polskiego porządku prawnego implementowana Ustawą z 2 marca 2000 roku o ochronie niektórych praw konsumentów oraz o odpowiedzialności za szkodę wyrządzoną przez produkt niebezpieczny (Dz.U Nr 22, poz. 271 z późn. zm.). Regulacja ta wprowadziła ograniczenia swobodnego kształtowania treści postanowień w stosunkach $\mathrm{z}$ konsumentami, przy czym poza obostrzeniami w zakresie prawa cywilnego przyznane zostały także kompetencje prezesowi UOKiK realizowane z wykorzystaniem prawa administracyjnego. Później ${ }^{6}$, w wyniku nowelizacji o ochronie konkurencji i konsumentów kompetencje te zostały poszerzone, a rola ochronnego mechanizmu cywilnoprawnego, w tym Sądu Ochrony Konkurencji i Konsumentów, uległa radykalnemu zmniejszeniu. Okazuje się zatem, że na przestrzeni ostatnich 20 lat centralna dla prawa prywatnego kategoria, jaką jest wolność umów, doznaje ograniczeń zarówno z wykorzystaniem instrumentarium cywilnoprawnego, jak i publicznoprawnego. Zjawisko to ma szerszy charakter, a wspomniane regulacje to zasadniczo wierzchołek góry lodowej. W ostatnich latach presja prawa publicznego na stosunki cywilnoprawne jest ogromna i przejawia się we wprowadzaniu kolejnych nakazów i zakazów w postaci różnorodnych taryf cenowych, wymogów formalnych, wzorców itp. ${ }^{7}$ Jest to tendencja, $\mathrm{z}$ jednej strony, zgodna $\mathrm{z}$ rozwojem cywilizacyjnym (coraz bardziej skomplikowany świat wymaga coraz bardziej szczegółowych reguł), z drugiej zaś - niepokojąco zbliżająca się do idei dogłębnego i zupełnego uregulowania relacji o charakterze cywilnoprawnym, z natury swej wolnościowych. Odnosząc

4 Por. P.J. Deneen, Dlaczego liberalizm zawiódl, Warszawa 2021; R. Woś, Dziecięca choroba liberalizmu, Warszawa 2014.

5 E. Fromm, Ucieczka od wolności, Warszawa 2021.

6 Począwszy od 17 kwietnia 2016 roku.

7 Przykłady opisanej polityki można by mnożyć, przykładowo ustawy regulujące kredyt konsumencki, timesharing, taryfy energetyczne, tak zwana ustawa deweloperska, regulacje dotyczące danych osobowych itp. 
opisany stan rzeczy do wspomnianego Frommowskiego sprzężenia zwrotnego, można stwierdzić, że wprowadzane ograniczenia wolności kontraktowej przekładają się na zwiększony poziom bezpieczeństwa jednostki, co — przy coraz bardziej zanonimizowanym obrocie oraz wzrastającej dysproporcji kontraktowej konsumenta oraz jego kontrahenta - stanowi wystarczające uzasadnienie racjonalności podejmowanych działań, jednak dzieje się to z pokrzywdzeniem autonomii woli jednostki. Tak postawionej tezy nie sposób zakwestionować, nie sposób także zakwestionować zasadności tych kierunków, choć pewien żal budzi jednak brak funkcjonujących mechanizmów autoregulacyjnych i wszechobecność oraz drobiazgowość regulacji.

Przechodząc od dotychczasowych rozważań natury ogólnej do konkretnych zagadnień dotyczących modeli wiązania wzorców umownych, wypada zacząć od formalnej dopuszczalności posługiwania się wzorcem umownym w obrocie gospodarczym - czy to dwustronnie profesjonalnym, czy konsumenckim. Na wstępie warto przypomnieć, że dopuszczalność stosowania wzorca umownego jest pochodną zasady swobody umów, ale może też jej się sprzeniewierzyć, prowadząc do jej ograniczenia. Zastosowanie wzorca sprawia, że negocjacje, których celem jest stworzenie forum do prezentacji oraz wyważenia interesów stron, zostają wyeliminowane, co najmniej zaś sprowadzone do minimum dotyczącego tylko essentialia negotii. Stosowanie wzorców umownych doprowadziło do faktycznego ograniczenia możliwości negocjowania, nie prowadząc jednak do ograniczenia zasady swobody umów. Trzeba jednak pamiętać, że zasada ta pełni funkcję służebną względem ogólniejszej reguły równości stron umowy oraz autonomii woli stron wyrażającej się w umożliwieniu jednostce kształtowania treści praw i obowiązków uwzględniających jej rzeczywisty interes. W przypadku zaś, gdy równość ta, na skutek sytuacji faktycznych wynikających z dysproporcji ekonomicznej, jest zachwiana poprzez nadużycie zasady swobody umów, prawo musi interweniować. Interwencja ta polega na wpływaniu przez ustawodawcę na treść postanowień narzuconych przez proponenta z wykorzystaniem wzorców za pośrednictwem przepisów o klauzulach niedozwolonych. Mamy tu do czynienia ze szczególnego rodzaju sytuacją polegającą na ratowaniu zasady swobody umów poprzez jej ograniczenie. Paradoksalnie zatem to, co wydaje się zaprzeczeniem wolnego rynku i swobody kontraktowania, leży w interesie działalności gospodarczej i służy wzmocnieniu zasady wolności umów. Przepisy o niedozwolonych postanowieniach umownych można traktować jako uszczegółowienie $\mathrm{z}$ art. $5 \mathrm{kc}$ W zW. z art. $353^{1} \mathrm{kc}$, wskazujących na formułę nadużycia prawa. W zaprezentowanym przypadku sprowadza się ono do stwierdzenia, iż proponent miał prawo posłużyć się wzorcem w oparciu o zasadę swobody umów ${ }^{8}$, jednak prawa tego

8 Swoboda umów wiąże się ściśle z możliwością negocjowania. To zaś, zdaniem J. Górskiego, należy traktować szeroko i pod pojęciem tym rozumieć „,wszelkie akty przygotowujące umowę, a również i okres czasu, w ciągu którego odnośne akty mają miejsce" (J. Górski, Zobowiązania, Warszawa 1971, s. 12). 
nadużył, naruszając tę samą zasadę przyznającą określone uprawnienia drugiej stronie.

Co do samych poglądów na temat charakteru wzorców umownych oraz zasad ich wiązania, nie budzi wątpliwości fakt, że zostały one zdominowane przez przedstawicieli nauki francuskiej i niemieckiej. Doktryna francuska za podstawowy problem uznała wpływ wzorców na zawarcie umowy przez przystąpienie, a zatem mechanizm wiązania postanowień wzorca $\mathrm{z}$ umową, co sprawiało, iż $\mathrm{w}$ istocie rzeczy przedmiotem zainteresowania była sama umowa ${ }^{9}$. Jako pierwszy zajął się tą problematyką Raymond Saleilles, jemu zresztą przypisuje się autorstwo terminu ,umowa adhezyjna”. Ogłoszonej przez niego w roku 1901 koncepcji umowy adhezyjnej zarzucano brak cech pozwalających na wyodrębnienie tego rodzaju umów, a także niestworzenie jej jednolitej definicji ${ }^{10}$, a jedynie przybliżenie pewnej praktyki rynkowej. $Z$ uwagi na przystąpienie przez jedną ze stron do umowy zaproponowanej w całości przez kontrahenta w ocenie krytyków umowa taka stawała się zatem ,produktem woli” tylko jednej strony. Saleilles dogmatycznie pojmował konsens i dlatego negował w tym kontekście walor umowy. W jego przekonaniu umowa powinna być wynikiem traktowanej poważnie „współpracy kontraktowej” stron, a sprowadzenie wyrażenia woli jednej z nich do akceptacji całości pozbawiało ją waloru ,uzgodnienia”. Saleilles nie zajmował się przy tym treścią wzorca, w jego przekonaniu sam akt umowy był wadliwy i dlatego nazywano go ,antykontraktualistą”. Późniejsza ewolucja poglądów na temat konsensu łagodziła stawiane wymagania, doprowadzając ostatecznie do zaaprobowania takiego sposobu zawarcia umowy. Na określenie przedstawicieli nurtu dopuszczającego zawarcie umowy w takim „uproszczonym” trybie używano zwrotu „kontraktualiści”. Jednocześnie stwierdzono, że ewentualne nieprawidłowości w treści postanowień wzorca powinny być oceniane z punktu widzenia prawa (a nie - jak uważano wcześniej — moralności). Oponentami Saleillesa byli działający na przełomie wieków Hauriou (1856-1929) oraz Duguit (18591928). Ten drugi głosił, że działanie danego podmiotu polegające na stworzeniu wzorca jest $\mathrm{w}$ istocie rzeczy wykreowaniem pewnego faktu, zdarzenia obejmującego treść wzorca, a zawarcie umowy z wykorzystaniem wzorca jest skorzystaniem przez adherenta $\mathrm{z}$ obiektywnego zjawiska, jakim jest istnienie wzorca, zatem konsens miał obejmować zgodę na treść umowy, a nie tylko na przystąpienie do niej. O ile Duguit w swoich koncepcjach odwoływał się do „obiektywnych

9 O mechanizmach oddziaływania woli na treść stosunku prawnego zob. Z. Radwański, Uwagi ogólne o autonomii woli, [w:] II Kongres Notariuszy Rzeczypospolitej Polskiej - referaty i opracowania, Poznań 1999, s. 257 oraz podaną tam literaturę.

10 Do dziś nie stworzono odpowiedniej definicji normatywnej. Doktryna wskazuje jedynie pewne cechy tego rodzaju umów, jak stałą i generalną ofert, istnienie monopolu lub drastycznej przewagi oferenta, świadczenie powszechnie poszukiwane, sformułowanie oferty jako gotowego lub prawie gotowego wzorca umowy z postanowieniami sformułowanymi na korzyść oferenta; por. także stanowiska takich autorów, jak J. Fortier, R. de Saint Remy, P. Pichon, M. Domergue, M. Planiol, G. Ripert, P. Esmain, przywoływane w: E. Łętowska, 1974, s 130. 
stanów rzeczy", Hauriou szedł znacznie dalej. Mimo że obaj naukowcy żyli w tym samym czasie, miedzy ich poglądami dostrzec można istotną różnicę. Hauriou swoimi teoriami dał pożywkę dla późniejszych twórców teorii normatywnych, którzy w znacznie większym stopniu w relacjach prywatnoprawnych opartych na wzorcu umownym dopatrywali się aktywności prawodawcy, nie tylko sankcjonującego stworzoną przez nich umowę, ale również w pewnym sensie biorącego udział w jej tworzeniu. Hauriou postulował koncepcję tak zwanej instytucji kolektywnej, to jest - zjawiska społecznie akceptowanego i wykazującego względną trwałość, które uznawał za sui generis źródło prawa bezwzględnego. Tego rodzaju przymiot Hauriou przyznał wzorcom umownym i dlatego uważał, że przystąpienie do umowy jest wyrazem zaakceptowania tak sformułowanego prawa o charakterze bardziej publicznym niż prywatnym (sic!). Aspekty publiczne w umowach adhezyjnych akcentował także René Demogue (18721938) głoszący, iż warunkiem zawarcia umowy nie jest opracowanie poszczególnych zapisów przez obie strony w ramach prowadzonych rokowań, a sam akt przystąpienia obejmujący jednocześnie zgodę na treść wzorca. Demogue był więc w zasadzie kontraktualistą — twierdził, że umowa adhezyjna z punktu widzenia jej konstrukcji jest bowiem taką samą umową jak umowa „zwykła”, od której różni się tylko technicznym sposobem zawarcia ${ }^{11}$, jednak istotne znaczenie mają konstrukcyjne elementy, na których opierała się jego teoria, dające - podobnie jak poglądy Hauriou - pożywkę dla późniejszych koncepcji, już pełnymi garściami czerpiących z idei totalitarnych. Zgodnie z zaprezentowanym przez Demogue rozumowaniem, skoro umowa adhezyjna jest zawierana masowo, dopuszczalność jej stosowania powinna być zdeterminowana nie tyle potrzebami przedsiębiorcy, ile społeczeństwa, a kontrakty tego rodzaju mają istotną funkcję społeczną (service public). Jak wynika z powyższego, poglądy doktryny francuskiej zasadniczo mieszczą się w nurcie kontraktualistycznym, choć w poglądach jej przedstawicieli dostrzec można pewne tendencje do podkreślania także normatywnego charakteru wzorców. Tendencje te w znacznie większym zakresie dały o sobie znać w nauce niemieckiej, co może być wynikiem zarówno tego, że od czasu proklamowania Cesarstwa Niemieckiego, 18 stycznia 1871 roku, kraj ten był mocno zbiurokratyzowany, o silnej strukturze państwowej, jak i faktu, że zasadniczo koncepcje te powstawały w okresie nieco późniejszym, kiedy to dochodziły do głosu idee głoszące dominację państwa nad jednostką, na margines spychające koncepcje liberalne. W późniejszym okresie idee te dały początek ideologii faszystowskiej, nazizmu i totalitaryzmu, w których ramach zagadnienia wiązania charakteru wzorców umownych wykazywały tendencje normatywistyczne. Jednak prekursorem niemieckich badań nad charakterem umów adhezyjnych był Levin Goldshmidt, który około roku 1860 stworzył podwaliny doktryny

11 Niektórzy autorzy z uwagi na odmienność techniczną, a także masowość stosowania proponują odmienną ocenę teoretyczną opisywanego zjawiska. Tak przykładowo A. Rieg, Le role de la volonte dans l'acte juridique en droit francais et allemand, Paryż 1961, s. 242. 
niemieckiej opisującej zjawisko wzorców umownych. Goldshmidt, zajmując się funkcjonowaniem regulaminu kompanii kolejowej, stwierdził, że wzorce są sui generis porządkiem prawnym (sic!) — a więc czymś znaczniejszym niż wyrazem woli kontraktowej stron oraz ekspresją ich autonomii. Uważał, że ów porządek prawny istnieje realnie i jest wprowadzany do treści umowy ratione impe$r_{i i}{ }^{12}$ (sic!). Wyznaczony przez niego kierunek rozwinięty został w tak zwaną teorię normatywistyczną ${ }^{13}$. Głoszono wówczas, że prawem jest to, co w świadomości ludzkiej uznaje się za obowiązujący porządek, w tym zwyczaje, układy zbiorowe oraz wzorce umowne (sic!). Według tworzącego później L. Raisera (1904-1980) wzorce umowne są zewnętrznie i funkcjonalnie podobne do prawa pozytywnego, ale w ostateczności nim nie są, choć jako że bywają traktowane przez niektóre środowiska na równi z prawem, należy nadać im charakter normatywny. Warto przy tym dodać, że swoje opus magnum — pracę habilitacyjną zatytułowaną Das Recht der Allgeminen Geschaftsbedingungen — poświęcone właśnie problematyce wzorców umownych L. Raiser opublikował w roku $1935^{14}$, a zatem w szczytowym okresie rozwoju ideologii totalitarnej w Niemczech. On sam nie zgadzał się z prowadzoną wówczas polityką oraz panującym ustrojem, za co zresztą spotkały go szykany ${ }^{15}$. Mimo dobrze ocenianej pracy habilitacyjnej nie dopuszczono go do prowadzenia wykładów, gdyż wraz z innymi wykładowcami protestował przeciwko zwalnianiu profesorów żydowskiego pochodzenia oraz innych osób, tak zwanych podejrzanych politycznie. Jego osobiste poglądy nie stały jednak na przeszkodzie dla czerpania z jego myśli naukowej przez skrajnych przedstawicieli ideologii faszystowskiej. Ewolucja teorii Raisera doprowadziła niektórych przedstawicieli doktryny III Rzeszy, jak na przykład Carla Schmitta (1888-1985), do kwestionowania jakiejkolwiek różnicy pomiędzy prawem stanowionym a wzorcami umów. Ten niemiecki prawnik, konstytucjonalista i politolog, specjalista w zakresie nauk o państwie i prawa międzynarodowego, filozof społeczny i teoretyk prawa, teoretyk państwa autorytarnego, zwolennik decyzjonizmu, współtwórca tak zwanej teologii politycznej, a także członek NSDAP

12 Podaję za: E. Łętowska, Problematyka ogólnych warunków $i$ wzorów umów w świetle pogladów doktryny obcej, „Studia Prawnicze” 1974, nr 3, s. 137.

13 O trafności tej nazwy niech świadczą używane w literaturze niemieckiej różnego rodzaju określenia na wzorce umowne, gdzie mówi się o nich jako o abstrakcyjnych normach umownych, tworach normatywnych o charakterze ponadumownym, wyrazie i wyniku występującej w najwyższym stopniu autonomii prywatnej tworzącej źródła prawa pozytywnego, prawie umownym drugiej instancji, wstępnym stopniu ustawy, umowach normatywnych (E. Łętowska, Wzorce umowne, ogólne warunki, wzory, regulaminy, Wrocław 1975, s. 34).

14 L. Reiser, Das Recht der allgeminen Geschaftsbedingungen, Bad Homburg 1935, s. 77 n.; za: E. Łętowska, Problematyka..., s. 138.

15 Świadczy o tym to, że jego praca habilitacyjna Das Recht der allgeminen Geschaftsbedingungen powstała w roku 1933, a z uwagi na obstrukcję ówczesnych władz została wydana dopiero dwa lata później. 
w latach $1933-1945^{16}$ twierdził, że wzorce umowne są de facto częścią porządku prawnego na takich samych zasadach jak prawo stanowione. Fakt tolerowania przez państwo wzorców umownych stanowił dla niego dowód ich akceptacji, tak jakby unormowania te pochodziły wprost z regulacji ustawowych. Koncepcja ta jako wyraz skrajnej ideologizacji prawa prywatnego po upadku faszystowskich Niemiec została odrzucona. Po roku 1945 przywrócono też rangę L. Raiserowi, który w toku dalszej kariery naukowej jako profesor Uniwersytetu w Getyndze stworzył w roku 1976 nowe regulacje wzorców umownych. Dziś także w Niemczech przyjmuje się, że oświadczenie o przystąpieniu do umowy nie musi obejmować wyraźnej i świadomej akceptacji wzorca, który mimo wszystko został objęty umową stron, przyznając tym samym prymat koncepcji konsensualnej. Dla funkcjonowania i postanowień wzorca nie ma zatem teoretycznego znaczenia, czy jego akceptacja polega na ,poddaniu się mu”17 — w takim przypadku oświadczenie o zawarciu umowy stanowiłoby swoiste conditio iuris dla zastosowania wzorca (niebędącego jednak częścią umowy) - czy też traktowania go przez strony ,jak własnego", objętego w całości treścią oświadczeń woli obu uczestników czynności. Współcześnie przyjmuje się zatem, że aby regulamin kształtował treść stosunku obligacyjnego, niezbędna jest zgoda adherenta. Wystarczające jest zatem oświadczenie woli wyrażające taką zgodę, bez konieczności objęcia świadomością wszystkich zapisów wzorca, co wiąże się z odejściem - zwłaszcza przez naukę niemiecką - od indywidualistycznej i liberalnej koncepcji autonomii woli, wskazując, że ma ona swoją doniosłość prawną (wiąże) tylko w granicach i w sposób wyznaczony w systemie prawnym ${ }^{18}$. O woli tej wnioskuje się na podstawie różnych przesłanek, nieraz również się ją formalizuje.

Formalizacja przesłanek zgody stanowi pewien wyłom w radykalnie pojmowanej wizji kontraktualistów i jest pewnym ukłonem w kierunku nurtów normatywistycznych. Ewolucja poglądów - od liberalno-kontraktowych głoszonych głównie przez przedstawicieli nauki francuskiej, do normatywnych, w skrajnej formie forsowanej przez C. Schmitta, doprowadziła do wypośrodkowania stosowanych konstrukcji prawnych poprzez wspomniane wkomponowanie w klasyczne teorie kontraktualistów elementu formalizacji zgody. W Polsce wskazuje na nią przepis art. $384 \mathrm{kc}$, zgodnie z którym ,ustalony przez jedną ze stron wzorzec umowy, w szczególności ogólne warunki umów, wzory umów, regulaminy wiążą drugą stronę, jeżeli zostały jej doręczone przy zawarciu umowy”. Nie wymaga się zatem zapoznania adherenta $\mathrm{z}$ treścią wzorca, poprzestając jedynie na umożliwieniu mu tego. Więcej nawet, w niektórych przypadkach nawet doręczenie nie jest

16 Por. https://pl.wikipedia.org/wiki/Carl_Schmitt (dostęp: 10.09.2021).

17 Tak R. Longchamps de Bérier, Polskie prawo cywilne. Zobowiązania, Lwów 1939 (reprint Poznań 1999), s. 177-178.

18 Z. Radwański, Prawo zobowiązań. Część ogólna, t. 3, cz. 1, Wrocław 1981, s. 5. Autor ten wymienia wielu przedstawicieli doktryny, w tym reprezentatywne stanowisko W. Flume'a (Allgemeiner Teil des Bugerlihen Rechts, Berlin-Heidelberg-New York 1979, s. 1). 
konieczne, wystarczy odwołanie się do ogólnie wymaganej wiedzy o zwyczajowym stosowaniu wzorca ${ }^{19}$.

Warto dodać, że w Polsce wzorce umowne nazywa się często lex contractus ${ }^{20}$. Termin ten stracił jednak na precyzji wobec uchylenia obowiązujących w okresie PRL przepisów statuujących zasady wiązania „czysto normatywnych”, a więc takich, które zostały ustanowione w aktach normatywnych i wiązały strony niezależnie od ich woli ${ }^{21}$. Szerzej na ten temat wypowiedział się Marek Leśniak ${ }^{22}$ w opracowaniu poświęconym normatywnym wzorcom umów spółek handlowych, przypominając, iż

w odniesieniu do wzorców normatywnych wydanych na podstawie art. $384 \S 1 \mathrm{KC}$ w pierwotnym brzmieniu E. Łętowska wskazywała słusznie, że ,gdy wzorzec zawiera postanowienia określające prawa i obowiązki stron, wówczas — zgodnie z art. $56 \mathrm{KC}$ - działanie wzorca na treść stosunku prawnego jest automatyczne i niezależne od woli stron - identyczne z działaniem innych przepisów prawa" ${ }^{23}$.

Autor ten, w pełni aprobując zaprezentowane stanowisko, przywołuje także tezę Z. Radwańskiego, który z kolei twierdził, iż

wydane na podstawie art. $384 \mathrm{KC}$ w pierwotnym brzmieniu ogólne warunki i wzory umów mają zawsze charakter przepisów prawnych, aczkolwiek mogą to być przepisy bezwzględnie albo względnie obowiązujące. W razie zawarcia konkretnej umowy współokreślają więc one treść stosunku prawnego przez wolę samego ustawodawcy (art. $56 \mathrm{KC}$ ) i dlatego nie wymagają przyjęcia przez strony w jakiejkolwiek postaci ${ }^{24}$.

W kontekście tematu niniejszego opracowania nie sposób pominąć faktu, iż opisane „czysto normatywne” wzorce umowne obowiązujące w okresie PRL stanowiły przykład „narzucania” przez państwo określonych rozwiązań umownych z wykorzystaniem władztwa legislacyjnego oraz naruszeniem zasad autonomii woli jednostki. Tego typu rozwiązanie konstrukcyjnoprawne mogło być wprowadzone między innymi dlatego, że przecież komunistyczna Polska z pewnością

19 Artykuł 384 kc: „W razie, gdy posługiwanie się wzorcem jest w stosunkach danego rodzaju zwyczajowo przyjęte, wiąże on także wtedy, gdy druga strona mogła się z łatwością dowiedzieć o jego treści. Nie dotyczy to jednak umów zawieranych $\mathrm{z}$ udziałem konsumentów, $\mathrm{z}$ wyjątkiem umów zwieranych w drobnych bieżących sprawach życia codziennego".

20 E. Gniewek, Podstawy prawa cywilnego i handlowego, Wrocław 1998, s. 40.

21 Artykuł 384 kc w pierwotnym brzmieniu: „§ 1. Rada Ministrów lub z jej upoważnienia inny naczelny organ administracji państwowej może ustalać ogólne warunki lub wzory umów dla określonej kategorii umów między jednostkami gospodarki uspołecznionej albo między tymi jednostkami a innymi osobami. $\S 2$. Przepisy przewidziane w paragrafie poprzedzającym mogą określać, w jakich granicach nie będą dopuszczalne postanowienia umowne odbiegające od ustalonych warunków lub wzorów umów".

22 M. Leśniak, Normatywne wzorce umów spótek handlowych w prawie polskim, Warszawa 2017 , s. 2.

23 Tak E. Łętowska, Wzorce..., s. 171.

24 Por. Z. Radwański, Prawo zobowiąań..., s. 395. 
nie należała do państw liberalnych i zdecydowanie bliżej jej było do ustrojów opartych na ideologiach totalitarnych.

Przeprowadzona analiza głównych nurtów doktryny w zakresie mechanizmu wiązania wzorców umownych wskazuje na korelację występującą pomiędzy ewolucją poglądów od liberalnych kontraktualistów po skrajnych normatywistów oraz funkcjonującymi w okresie zachodzenia tego procesu ideologiami o charakterze politycznym. Charakterystyczne jest, że szczytowy okres ideologii autorytarnej w Niemczech pokrywa się z poglądem niemal odmawiającym analizowanemu mechanizmowi cech relacji umownej opartej na równości stron i w drastyczny sposób ograniczającej autonomię woli jednostki ekonomicznie słabszej, będącej adresatem propozycji zastosowania wzorca przez dominującego w danym układzie proponenta. Wzgląd na istnienie wspomnianej korelacji pozwala na sformułowanie tezy, że właściwe ideologiom totalitarnym ograniczenie praw jednostki dokonujące się zwykle z wykorzystaniem mechanizmów prawa publicznego zaznaczało się także wyraźnie w obszarze prawa prywatnego $\mathrm{w}$ tak symbolicznym dla niego obszarze, jakim jest swoboda kontraktowania z wykorzystaniem wzorców umownych, stanowiąca $\mathrm{w}$ istocie podstawowy przejaw autonomii woli jednostki.

\section{Bibliografia}

Deneen P.J., Dlaczego liberalizm zawiódt, Warszawa 2021.

Flume W., Allgemeiner Teil des Bugerlihen Rechts, Berlin-Heidelberg-New York 1979.

Fromm E., Ucieczka od wolności, Warszawa 2021.

Gniewek E., Podstawy prawa cywilnego i handlowego, Wrocław 1998.

Górski J., Zobowiązania, Warszawa 1971.

Kaczor J., Zasada autonomii woli w świetle filozofii liberalnej, „Ruch Prawniczy, Ekonomiczny i Socjologiczny" 2001, nr 1-2.

Leśniak M., Normatywne wzorce umów spółek handlowych w prawie polskim, Warszawa 2017.

Longchamps de Bérier R., Polskie prawo cywilne. Zobowiąania, Lwów 1939 (reprint Poznań 1999). Łętowska E., Problematyka ogólnych warunków i wzorów umów w świetle poglądów doktryny ob$c e j$, ,Studia Prawnicze” 1974, nr 3.

Łętowska E., Wzorce umowne, ogólne warunki, wzory, regulaminy, Wrocław 1975.

Radwański Z., Prawo zobowiazań. Część ogólna, t. 3, cz. 1, Wrocław 1981.

Radwański Z., Uwagi ogólne o autonomii woli, [w:] II Kongres Notariuszy Rzeczypospolitej Polskiej - referaty i opracowania, Poznań 1999.

Reiser L., Das Recht der allgeminen Geschaftsbedingungen, Bad Homburg 1935.

Rieg A., Le role de la volonte dans l'acte juridique en droit francais et allemand, Paryż 1961.

Woś R., Dziecięca choroba liberalizmu, Warszawa 2014. 